\title{
Bogue Phalia Watershed in Mississippi Selected for a National Water- Quality Study
}

The U.S. Geological Survey (USGS) is studying seven watersheds across the Nation to better understand how natural factors and agricultural management practices (AMPs) affect the transport of water and chemicals. Natural factors include climate and landscape (soil type, topography, geology), and AMPs include practices related to tillage, irrigation, and chemical application. The study approach is similar in each watershed so that we can compare and contrast the results and more accurately predict conditions in other agricultural settings.

\section{Study objectives}

- Understand the links between the sources of water and agricultural chemicals (nutrients and pesticides) and their behavior and transport through the environment

- Predict the behavior and transport of water and agricultural chemicals in other agricultural areas not being studied

- Evaluate what the study results mean for management of water and water quality in a variety of agricultural settings

\section{We appreciate your help}

We are working with local growers and land owners to gain access to study sites. We also need information about the study area and about current as well as historical agricultural management practices-past practices also affect concentrations of agricultural chemicals in ground and surface water.

We will report the findings of the study in public meetings and in publications. These findings will provide information that will be useful for improving agricultural management locally and nationally, and will guide future studies in other watersheds.

\section{Why study the Bogue Phalia watershed?}

The Bogue Phalia and the other six watersheds represent nationally important agricultural settings (chemical use, crops, and AMPs) and natural settings (climate, geology, topography, and soils). The Bogue Phalia, which is part of the Yazoo River watershed, is representative of cotton, rice, and soybean row cropping in the humid, subtropical southeastern United States.

Other features of the watershed relevant to this study:

- Use of agricultural chemicals: Chemicals used include herbicides such as atrazine, metolachlor, and glyphosate; insecticides such as methyl parathion and malathion; and fertilizers, both organic and inorganic.

- Distinct natural setting: Rich alluvial soils, a long growing season, and a plentiful water supply (both rainfall and ground water) make the Bogue Phalia watershed one of the most agriculturally productive areas in the Nation. High annual rainfall combined with the flat topography and relatively impermeable clay soils increases the amount of water and chemicals that move overland to streams and into the Bogue Phalia.

- Variety of agricultural management practices: AMPs include tillage and no-tillage; use of central pivot irrigation; grassy waterways; landforming; use of slotted board risers, edge-offield buffer strips, and riparian buffer zones.

- Water-quality issues: Pesticides, especially herbicides, have been frequently detected in surface water, rainfall, and in the atmosphere in the alluvial plain of the Mississippi River (findings of USGS studies since the 1990s).

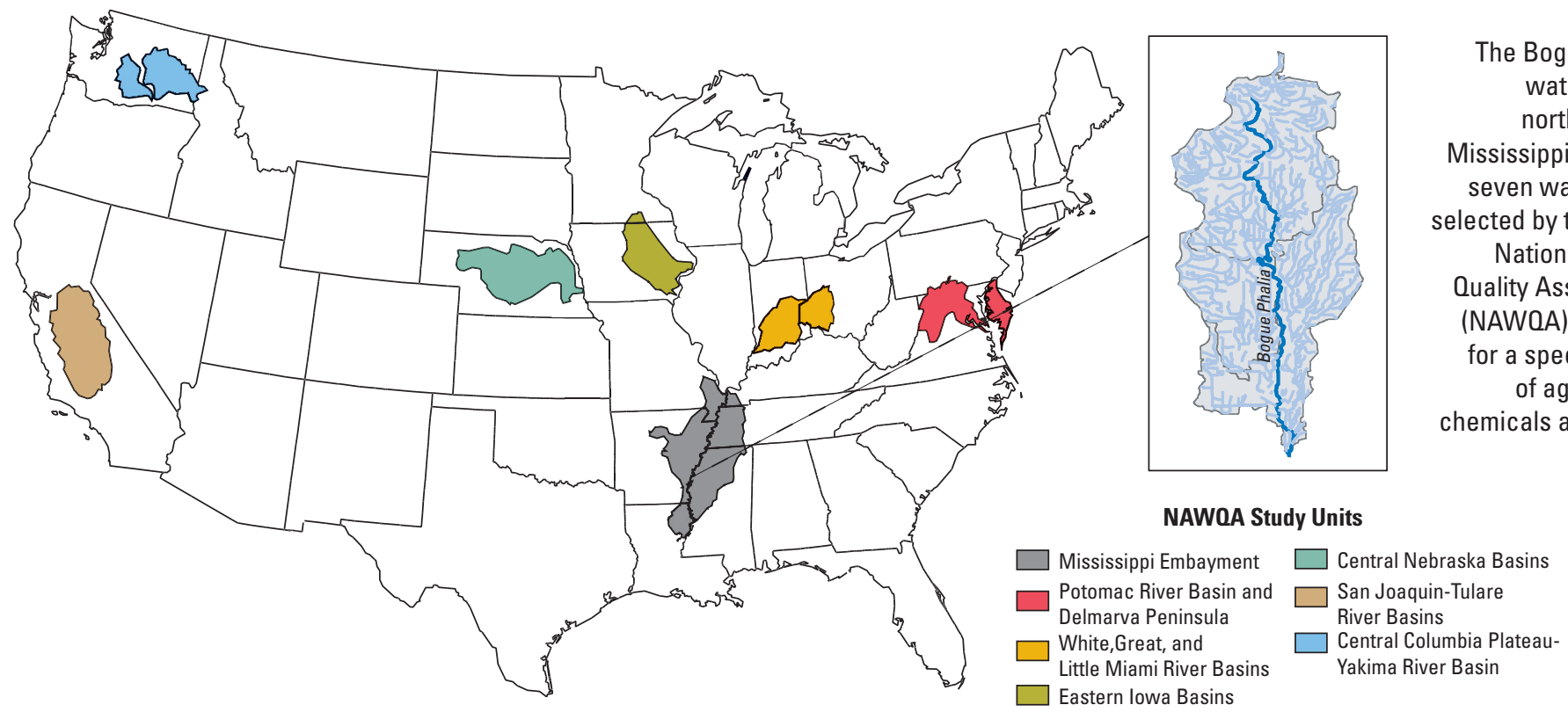


At a typical study site, several methods are used to collect water and chemical samples from the air, soil, surface water, and ground water.

After being applied to the land surface, agricultural chemicals can move upward into the atmosphere, downward through the soil to shallow ground water and underlying aquifers, eventually discharge to streams or run off across the land into streams, and move downstream to reservoirs and coastal waters. This process can take days, weeks, or even decades if water moves underground through the ground-water system.

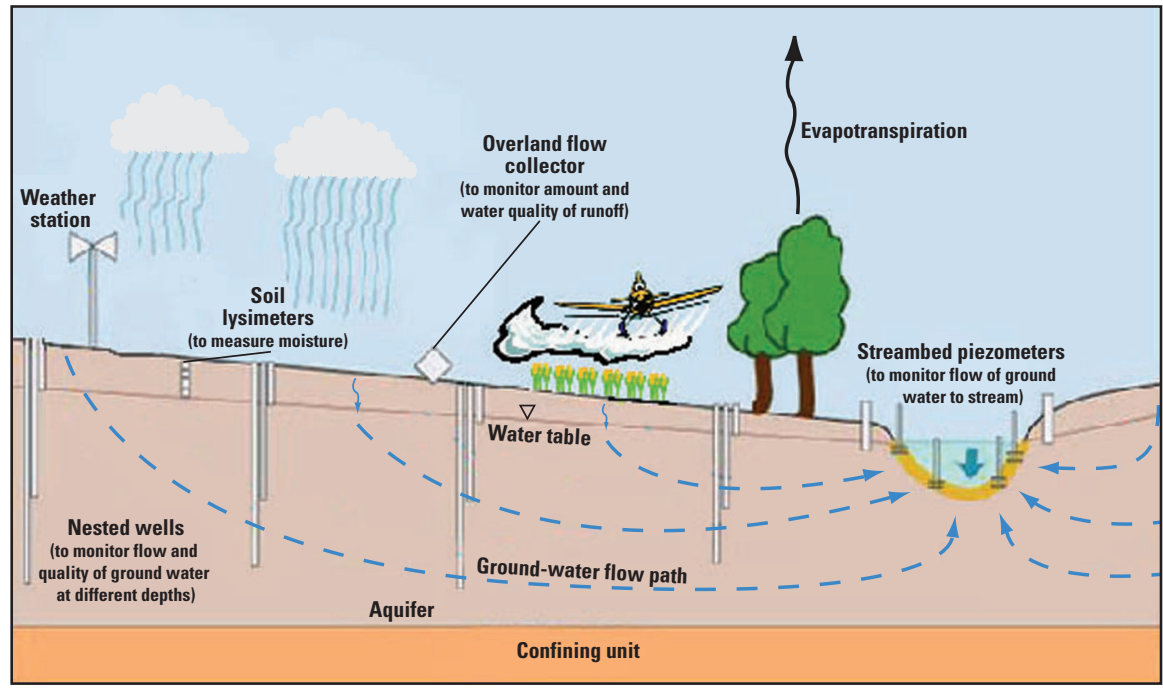

\section{Data Collection in the Bogue Phalia Watershed, 2007-2008}

\section{What kind of data}

Meteorological data, including rainfall, wind speed and direction, solar radiation, and air temperature. Soil data, including temperature and moisture

Amount of streamflow at Bogue Phalia near Leland, MS, gaging station and at an unnamed tributary upstream of the gaging station

Quality of stream water, runoff water, and rain water ${ }^{1}$

Ground-water levels in wells

Quality of ground water, soil water, and shallow water in and around streambed/riparian zone ${ }^{1}$

Quality of sediment in streambed and soils in agricultural fields ${ }^{1}$

\section{Why the data are collected}

To determine amount of precipitation, how much water from land surface reaches the water table, and how much is lost to evapotranspiration

To interpret water-quality data correctly (the amount of water in streams affects chemical concentrations)

To quantify the transport and behavior of natural and agricultural chemicals

To determine direction of ground-water flow, which affects transport of chemicals

To quantify the transport and behavior of natural and agricultural chemicals

To quantify the storage, behavior, and transport of water and chemicals in the soils and sediment
Continuously (since 1995) at Bogue Phalia. Real-time data available at http://waterdata.usgs.gov/ms/nwis/uv?site_ $n o=07288650$

Several times a year $(>14$ samples) for 2 years, with intensive sampling during application seasons

At least quarterly in some wells, continuously in others for at least 1 year

At least quarterly for 1 year

At least once during study

${ }^{1}$ In this study, water-quality and sediment-quality data include concentrations of nutrients (nitrogen and phosphorous), pesticides and pesticide breakdown products, and natural constituents and properties, including major ions (calcium, magnesium, chloride, etc.), organic carbon, dissolved oxygen, and temperature.

\section{We would like to thank}

Delta Council

Mississippi State University

Yazoo Mississippi Delta Joint Water Management District

\section{For more information}

Richard Coupe, Lead Scientist

(601) 933-2982,rhcoupe@usgs.gov

Paul Capel, Team Leader, National study

(612)625-3082, capel@usgs.gov

NAWOA Program http://water.usgs.gov/ nawqa

\section{Publication}

Kleiss, B.A., Coupe, R.H., Gonthier, G.J., and Justus, B.G., 2000, Water Quality in the Mississippi Embayment, Mississippi, Louisiana, Arkansas, Missouri, Tennessee, and Kentucky, 1995-98, U.S. Geological Survey Circular 1208, 36 p. Available online at http://water.usgs.gov/pubs/circ/ circ1208/ 